POLITYKA ENERGETYCZNA - ENERGY POLICY JOURNAL

$2020 \uparrow$ Volume $23 \uparrow$ Issue $4 \uparrow 141-154$

DOI: $10.33223 / \mathrm{epj} / 130319$

Svitlana KALININA ${ }^{1}$, Olena LyNDIUK ${ }^{2}$, Volodymyr BuchYK ${ }^{3}$

\title{
The development of renewable energy in Ukraine in the context of ensuring public employment
}

ABSTRACT: The article examines the trends in the development of renewable energy in Ukraine in accordance with the long-term strategy of the energy sector of the state in the context of the transformation of employment in the energy sector of the country. It is emphasized that investments in renewable energy technologies create more jobs compared to traditional electricity generation technologies. It is defined that in Ukraine there is a significant untapped potential for energy efficiency, which requires accelerating the pace of modernization and development of renewable energy sources and raises the issue of labor supply to the industry. It was emphasized that there are a number of opportunities for the development of the energy sector of Ukraine related to the development of renewable energy sources. It is underlined that the formation of territorial-industrial clusters in Ukraine for the production of equipment for solar and wind energy with a closed production cycle forms long-term prerequisites for socio-economic stability in the country and stimulates employment. It is

$\triangle$ Corresponding Author: Olena Lyndiuk; e-mail: lundyuk@ukr.net

${ }^{1}$ Ukrainian State Employment Service Training Institute, Theoretical and Applied Economics Department, Kyiv, Ukraine; ORCID iD: 0000-0002-2892-0410; e-mail: svitlana@skalinina.com.ua

2 Ukrainian State Employment Service Training Institute, Kyiv, Ukraine; ORCID iD: 0000-0003-4503-5912, e-mail: lundyuk@ukr.net

3 State Agency on Energy Efficiency and Energy Saving of Ukraine, Strategic Development Department, Kyiv, Ukraine; ORCID iD: 0000-0003-0680-1215; e-mail: volodymyr.buchyk@gmail.com

2020. The Author(s). This is an open-access article distributed under the terms of the Creative Commons Attribution-ShareAlike International License (CC BY-SA 4.0, http://creativecommons.org/licenses/by-sa/4.0/), which permits use, distribution, and reproduction in any medium, provided that the Article is properly cited. 
substantiated that an important reserve for increasing employment in Ukraine is to ensure the energy efficiency of buildings. At the same time, it was noted that in the field of renewable energy and energy efficiency in Ukraine there is a significant shortage of qualified technicians and specialists in the field of innovative technologies, which confirms the importance of studying the problem of labor support in the industry. It is determined that today the solution of the issue of labor supply of the industry takes place mainly at the level of enterprises that invest in the development of their own staff.

KEYWORDS: renewable energy, energy efficiency, electricity, solar energy, wind energy, employment, labor supply

\section{Introduction}

The development of the energy sector of Ukraine's economy is influenced by a number of factors, both positive and negative. On the one hand, the trends in the development of the energy sector are negatively affected by the situation in Eastern Ukraine and the state of the labor market; on the other hand, the development of the industry is stimulated by such factors as the long-term government strategy for the development of the energy sector, the active attraction of investment. In particular, there are a number of opportunities for the development of Ukraine's energy sector related to the development of renewable energy sources.

In 2017, Ukraine adopted the Energy Strategy until 2035 (MEPR 2017), the priority areas of which are the development of renewable energy, energy efficiency and energy saving. In 2020, the country approved the Concept for the implementation of state policy in the field of energy efficiency of buildings in terms of increasing the number of nearly zero-energy buildings (RADA 2020). Ukraine also joined the International Renewable Energy Agency (IRENA) (IRENA), which provides the country with access to the Abu Dhabi Development Fund and the IRENA database, as well as a platform for cooperation with leading countries in the field of renewable energy.

\section{General trends in the development of renewable energy}

In modern conditions in the world economy, attention is growing to the issue of energy efficiency, which leads to a change in electricity generation technologies in favor of renewable energy sources and leads to the transformation of employment in the energy sector. Today in the world the share of electricity produced from renewable sources in total energy consumption is $26 \%$, by 2030 this indicator is expected to increase to $55 \%$ (GIZ 2020). 
Renewable energy production is growing extremely fast. According to experts, by 2040, alternative energy sources will meet more than $40 \%$ of world demand (Kyiinfo 2020). At the same time, employment in renewable energy is constantly increasing (Fig. 1) (in 2018, about 11 million people worked in this industry), and investment in renewable energy technologies, compared to traditional technologies for electricity production, create more jobs per 1 USD investments (employment in the energy sector consists of permanent jobs for employees at electricity generation facilities and subcontractors - direct employment; jobs of personnel employed in the supply chains of the industry - indirect employment; jobs created as a result of the formation of the purchasing power of the above categories of employees - induced employment) (GIZ 2020).

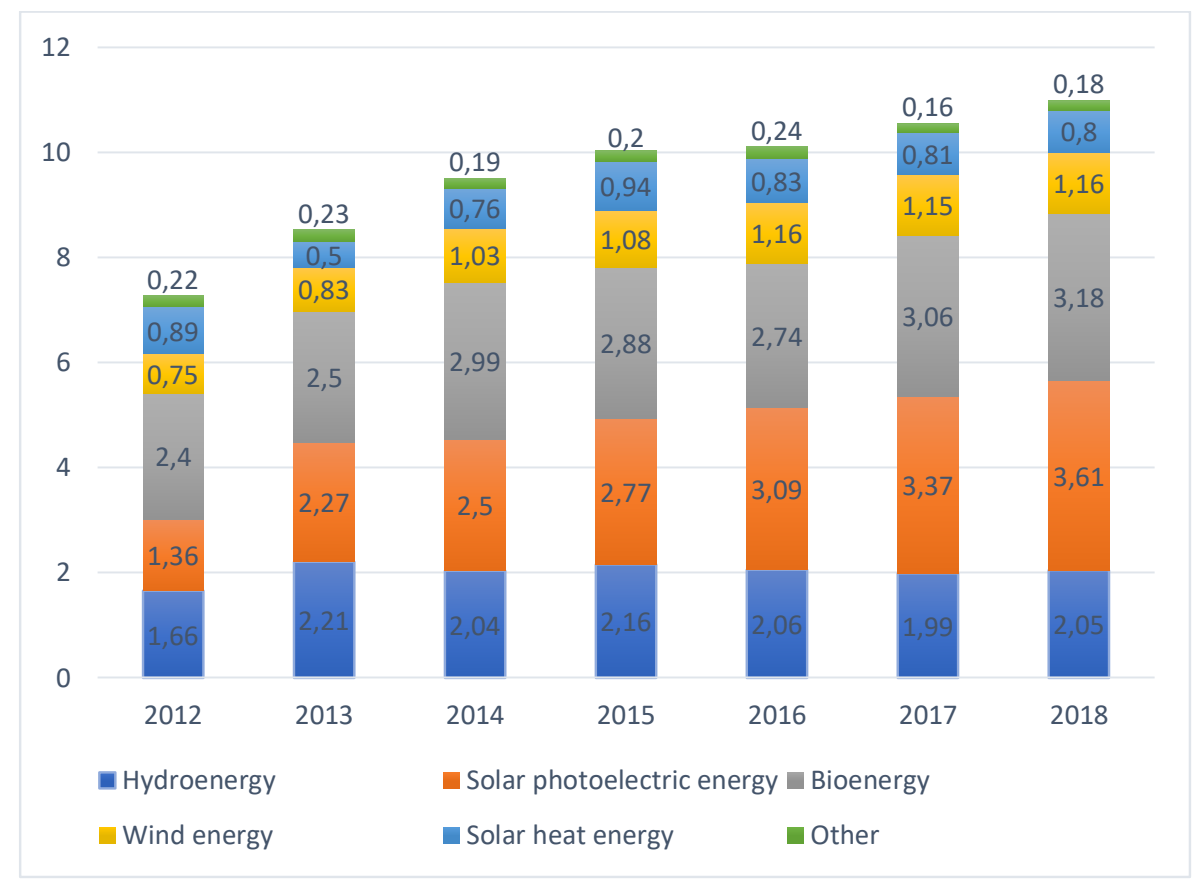

Fig. 1. The structure of employment by renewable energy sector in the world in 2018 [thousand people] Source: IRENA 2019

Rys. 1. Struktura zatrudnienia w różnych działach energetyki odnawialnej na świecie w 2018 roku [tys. osób]

Thus, according to the University of California, Berkeley, each job in the field of solar energy (per $1 \mathrm{MW}$ of input capacity) creates from 1.8 to 2.8 jobs in other sectors of the economy, in the field of wind energy -1.59 jobs (Aldieri et al. 2020).

According to the International Energy Agency (IEA) 2020 report (IEA 2020), Ukraine has significant untapped potential for energy efficiency (IEA U 2020). Today, the country's energy sector, which is mainly focused on the use of fossil fuels, including natural gas and coal (Table 1) 
(MEPR 2017), needs to accelerate the pace of modernization and the development of renewable energy sources, which also highlights the problem of providing the industry with labor resources capable of promoting a green transition.

TABLE 1. Structure of the total volume of primary energy supply in Ukraine [\%]

TABELA 1. Struktura dostaw energii pierwotnej na Ukrainie [\%]

\begin{tabular}{|l|c|c|c|c|c|}
\hline \multicolumn{1}{|c|}{ Source of primary energy supply } & 2015 & $2020^{*}$ & $2025^{*}$ & $2030^{*}$ & $2035^{*}$ \\
\hline Coal & 30.4 & 22.0 & 16.1 & 14.3 & 12.5 \\
\hline Natural gas & 28.9 & 29.3 & 31 & 30.8 & 30.2 \\
\hline Oil products & 11.6 & 11.5 & 9.2 & 8.2 & 7.3 \\
\hline Nuclear energy & 25.5 & 29.3 & 32.2 & 29.7 & 25.0 \\
\hline Biomass, biofuel and energy from waste & 2.3 & 4.9 & 6.9 & 8.8 & 11.5 \\
\hline Wind and solar & 0.1 & 1.2 & 2.4 & 5.5 & 10.4 \\
\hline Hydroenergy & 0.5 & 1.2 & 1.1 & 1.1 & 1.0 \\
\hline Heat energy & 0.6 & 0.6 & 1.1 & 1.6 & 2.1 \\
\hline The total supply of primary energy & 100 & 100 & 100 & 100 & 100 \\
\hline Fossil resources & 96 & 92 & 88 & 83 & 75 \\
\hline Renewable resources & 4 & 8 & 12 & 17 & 25 \\
\hline
\end{tabular}

* forecast.

Source: MPE 2017.

Thus, according to the National Renewable Energy Action Plan, the total capacity of renewable energy sources in 2030 is expected to reach $12.6 \%$ (excluding large hydropower capacities). According to forecasts, the capacity of solar energy will be increased to $2300 \mathrm{MW}$, wind - to $2280 \mathrm{MW}$ and bioenergy - to $950 \mathrm{MW}$ (EAP 2018).

According to the State Agency on Energy Efficiency and Energy Saving, in 2019, EUR 3.7 billion were invested in the development of renewable energy sources in Ukraine, which allowed to put $4.5 \mathrm{GW}$ of new capacity into operation and almost triple the production of electricity from renewable energy sources to a total of $6.8 \mathrm{GW}(5.5 \%$ of total electricity production in the country) (SAEE 2020).

Given that at the beginning of 2020, $4925 \mathrm{MW}$ of capacity was installed in Ukraine at solar power plants and $1170 \mathrm{MW}$ - at wind farms, induced employment in the country can be estimated at 8,865-13,790 people and 1860 people, respectively. In general, the induced effects of employment in these types of energy are estimated at 10.7-15.7 thousand jobs. In general, during 2014-2019, solar and wind energy of Ukraine provided employment for almost 25 thousand workers, and taking the stage of production of equipment -45 thousand workers into account (GIZ 2020).

At the same time, the renewable energy sector is the most diversified energy sector of the state in terms of investment structure (Fig. 2) (30\% of investments are foreign investors, 
$30 \%$ - large business, $30 \%$ - small and medium business, $10 \%$ - households) and in terms of the structure of electricity producers ( 800 stations and about 25 thousand households) (GIZ 2020). The total need for investment in this area in the country by 2030 is estimated at EUR 4 billion annually. According to the Concept of Green Energy Transition (MEPR 2020), bringing the share of renewable energy sources in the structure of electricity production to $70 \%$ by 2050 will allow Ukraine to completely abandon the most environmentally harmful coal generation.

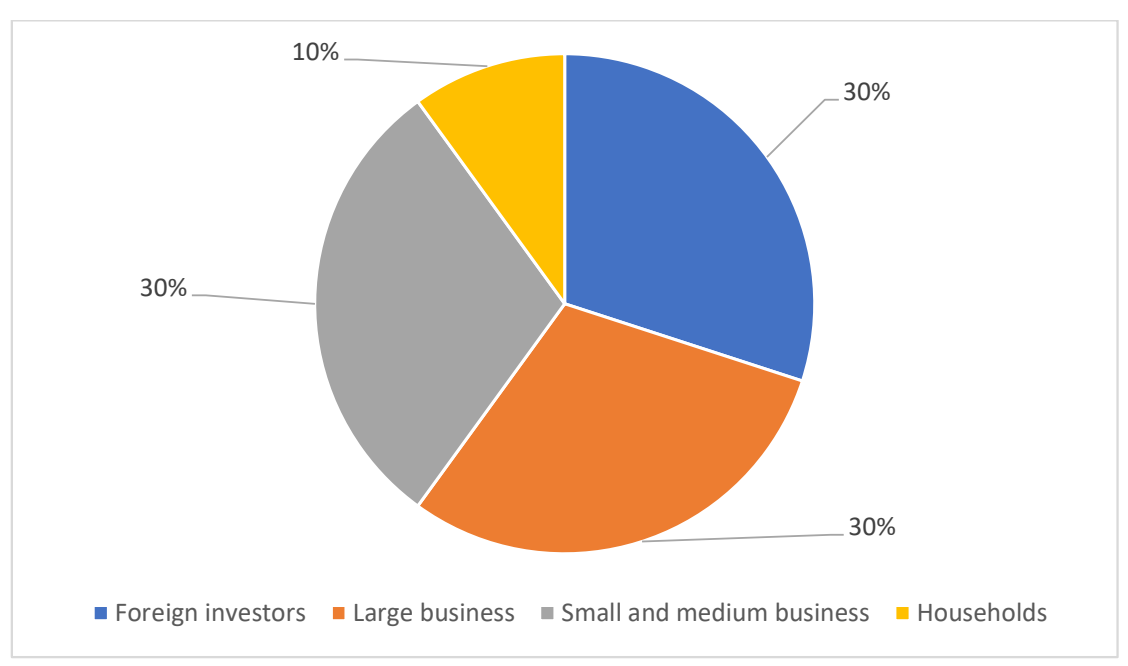

Fig. 2. The structure of investments in the production of electricity from renewable sources in Ukraine in 2019 Source: GIZ 2020

Rys. 2. Struktura inwestycji w produkcję energii elektrycznej ze źródeł odnawialnych na Ukrainie w 2019 roku

The green energy transition is also designed to significantly stimulate the development of high-tech production in Ukraine, leading to increased demand for goods and services related to "clean" technologies. This will have a direct impact on economic growth, job creation and increasing incomes of Ukrainian citizens (MEPR 2020).

\section{Employment in solar energy in Ukraine}

In 2014-2019, 40,791 people were employed in the field of solar energy in Ukraine, and without taking into account the stage of equipment production, 21,955 people were employed in solar energy (53.82\% of the total number of employees). In general, the employment of workers in the construction and operation of solar power plants in Ukraine is as follows by stages (without 
decommissioning): project planning $-1.95 \%$ of employees, equipment production $-46.18 \%$, transportation $-3.19 \%$, installation and grid connection $-36.21 \%$, maintenance and technical management $-12.47 \%$ (Fig. 3).

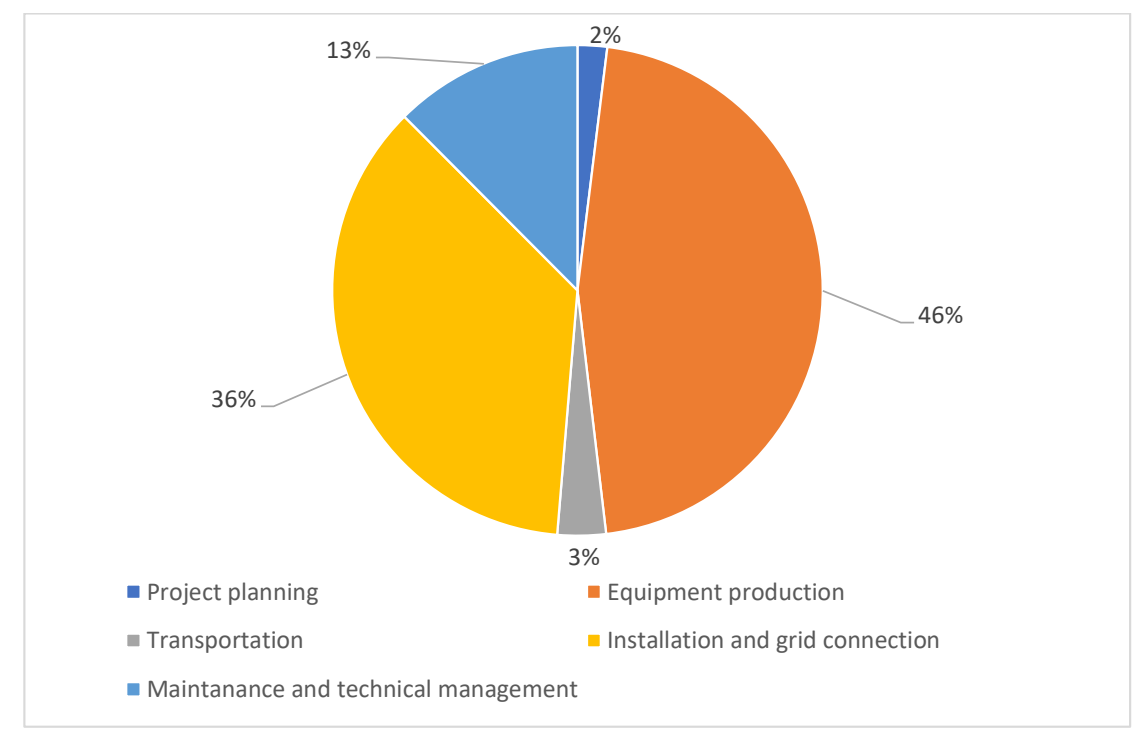

Fig. 3. The structure of employment of workers in the construction and operation of solar power plants in Ukraine Source: GIZ 2020

Rys. 3. Struktura zatrudnienia pracowników przy budowie i eksploatacji elektrowni słonecznych na Ukrainie

By occupational groups, the distribution of employment is as follows: construction workers and technical staff $-38.6 \%$, industrial workers and technicians $-30.31 \%$, equipment maintenance and technical management workers $-12.47 \%$ of employees (EAP 2018) (Table 2). This structure of employment is dictated by the active stage of production of solar panels and the construction of power plants in Ukraine.

Thus, in 2019, KNESS PV started operating in Vinnytsia - the first large-scale industrial production of panels for solar power plants in Ukraine, which allowed to produce in the country $100 \%$ of components for the solar energy industry (Kness 2019). Production capacity is $200 \mathrm{MW}$, another $200 \mathrm{MW}$ will be added at the start of the second stage of production. In total, since the launch of the plant 12 industrial photovoltaic plants with a total capacity of $70.66 \mathrm{MW}$ using solar modules manufactured by KNESS PV have been built in Ukraine. 
TABLE 2. Employment of workers in the construction and operation of solar power plants in Ukraine, by professional groups and stages in 2014-2019 [persons]

TABELA 2. Zatrudnienie pracowników przy budowie i eksploatacji elektrowni słonecznych na Ukrainie według grup zawodowych i etapów w latach 2014-2019 [osoby]

\begin{tabular}{|c|c|c|c|c|c|c|}
\hline Professional groups & 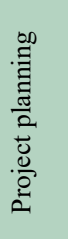 & 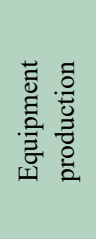 & 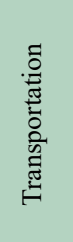 & 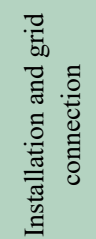 & 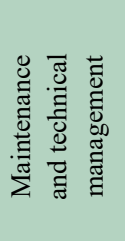 & 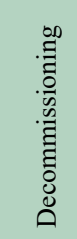 \\
\hline $\begin{array}{l}\text { Experts in legal, energy regulation, real estate } \\
\text { and taxation, standardization }\end{array}$ & 309 & 696 & 0 & 0 & 43 & 0 \\
\hline Financial analysts & 199 & 0 & 0 & 0 & 0 & 0 \\
\hline Electrical, mechanical and energy engineers & 144 & 0 & 0 & 143 & 740 & 86 \\
\hline Logistics experts & 94 & 0 & 0 & 0 & 0 & 0 \\
\hline Environmental experts & 34 & 0 & 0 & 113 & 0 & 69 \\
\hline Occupational safety experts & 15 & 696 & 0 & 300 & 980 & 64 \\
\hline Industrial workers and technicians & 0 & 11,972 & 0 & 0 & 390 & 0 \\
\hline $\begin{array}{l}\text { Industrial engineers, telecommunications } \\
\text { and electricity engineers }\end{array}$ & 0 & 1943 & 0 & 0 & 0 & 0 \\
\hline Chemical engineers & 0 & 289 & 0 & 0 & 0 & 0 \\
\hline Marketing and sales staff & 0 & 866 & 0 & 0 & 0 & 0 \\
\hline Truck drivers and crane operators & 0 & 0 & 899 & 0 & 0 & 278 \\
\hline Loaders & 0 & 0 & 300 & 0 & 0 & 0 \\
\hline Administrative staff & 0 & 919 & 39 & 0 & 67 & 0 \\
\hline Shipping agents & 0 & 0 & 39 & 0 & 0 & 0 \\
\hline Geotechnical experts & 0 & 761 & 13 & 0 & 0 & 32 \\
\hline Quality control experts & 0 & 696 & 13 & 38 & 0 & 0 \\
\hline Construction workers and technical staff & 0 & 0 & 0 & 13,315 & 2,431 & 1,407 \\
\hline Civil engineers and construction foremen & 0 & 0 & 0 & 863 & 0 & 0 \\
\hline Operators & 0 & 0 & 0 & 0 & 413 & 0 \\
\hline Management & 0 & 0 & 0 & 0 & 21 & 0 \\
\hline Total & 795 & 18,837 & 1303 & 14,770 & 5,086 & 1,935 \\
\hline
\end{tabular}

Source: GIZ 2020. 


\section{Employment in wind energy in Ukraine}

In 2014-2019, 4219 people were employed in the field of wind energy in Ukraine (excluding the decommissioning stage). The structure of employment of workers in the construction and operation of wind power plants in Ukraine is as follows by stages: project planning $-4.34 \%$ of employees, equipment production $-31.83 \%$, transportation $-1.47 \%$, installation and connection to the grid $-57.88 \%$, maintenance and technical management $-4.48 \%$, decommissioning $14.13 \%$ (Fig. 4). As no wind power plant was dismantled in Ukraine during this period, the employment of employees in this type of activity can be considered as a general additional potential for future periods (2531 employees).

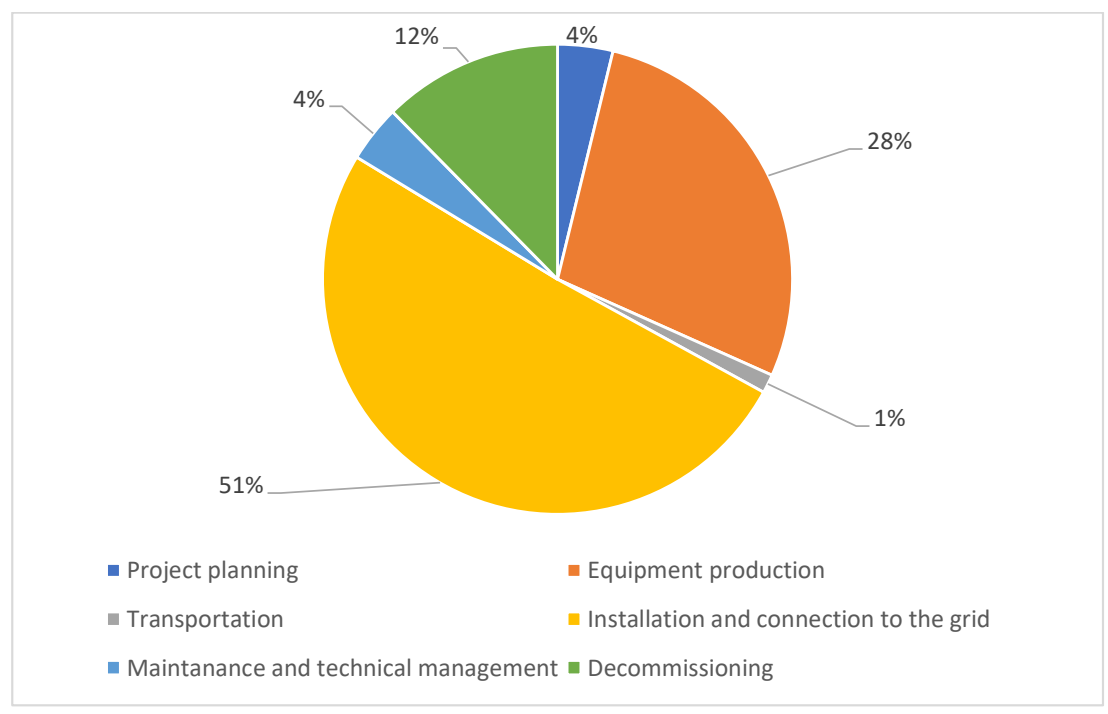

Fig. 4. The structure of employment of workers in the construction and operation of wind power plants in Ukraine Source: GIZ 2020

Rys. 4. Struktura zatrudnienia pracowników przy budowie i eksploatacji elektrowni wiatrowych na Ukrainie

By occupational groups, the distribution of employment is as follows: construction workers and technical staff $-45.27 \%$, industrial workers - $20.88 \%$; maintenance and technical management of onshore wind power plants $-4.48 \%$ (Table 3) (EAP 2018). Excluding the production of equipment, 2876 people $(68.24 \%$ ) out of the total number of employees were employed in the wind energy of Ukraine. As in the situation with solar energy, the structure of employment is determined by the production capacity and installation of wind turbines in the country.

Thus, in 2012 in Kramatorsk, on the basis of Kramatorsk Heavy Machine Tool Plant and Energomashspetsstal Plant, for the first time in the post-Soviet space Fuhrlander FL2500 esta- 
TABLE 3. Employment of workers in the construction and operation of onshore wind farms in Ukraine, by professional groups and stages in 2014-2019 [persons]

TABELA 3. Zatrudnienie pracowników przy budowie i eksploatacji lądowych farm wiatrowych na Ukrainie w podziale na grupy zawodowe i etapy w latach 2014-2019 [osoby]

\begin{tabular}{|c|c|c|c|c|c|c|c|}
\hline Professional groups & 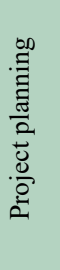 & 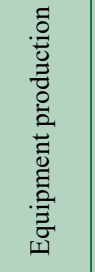 & 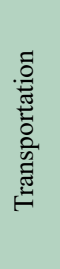 & 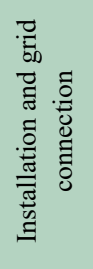 & 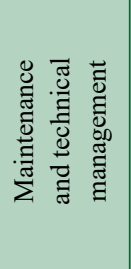 & 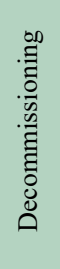 & 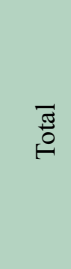 \\
\hline $\begin{array}{l}\text { Experts in legal, energy regulation, } \\
\text { real estate and taxation, standardization }\end{array}$ & 72 & 1 & 4 & 0 & 6 & 0 & 83 \\
\hline Financial analysts & 52 & 0 & 0 & 0 & 0 & 0 & 52 \\
\hline Logistics experts & 25 & 75 & 4 & 17 & 0 & 3 & 124 \\
\hline Electrical, mechanical and energy engineers & 21 & 0 & 0 & 27 & 0 & 30 & 78 \\
\hline Environmental experts & 6 & 0 & 0 & 51 & 6 & 24 & 87 \\
\hline Occupational safety experts & 4 & 76 & 0 & 108 & 11 & 22 & 221 \\
\hline Geotechnical experts & 4 & 0 & 0 & 0 & 0 & 0 & 4 \\
\hline Marketing and sales staff & 0 & 74 & 0 & 0 & 0 & 0 & 74 \\
\hline Industrial workers & 0 & 881 & 0 & 0 & 0 & 0 & 881 \\
\hline Industrial engineers & 0 & 71 & 0 & 0 & 0 & 0 & 71 \\
\hline $\begin{array}{l}\text { Telecommunication engineers and computer } \\
\text { engineers }\end{array}$ & 0 & 1 & 0 & 0 & 26 & 0 & 27 \\
\hline Truck drivers and crane operators & 0 & 0 & 44 & 212 & 0 & 127 & 383 \\
\hline Loaders & 0 & 0 & 2 & 0 & 0 & 0 & 2 \\
\hline Administrative staff & 0 & 61 & 9 & 0 & 9 & 0 & 79 \\
\hline Quality control experts & 0 & 75 & 0 & 7 & 0 & 0 & 82 \\
\hline Construction workers and technical staff & 0 & 0 & 0 & 1,884 & 26 & 390 & 2,300 \\
\hline Civil engineers and construction foremen & 0 & 0 & 0 & 136 & 0 & 0 & 136 \\
\hline Operators & 0 & 0 & 0 & 0 & 78 & 0 & 78 \\
\hline Management & 0 & 27 & 0 & 0 & 3 & 0 & 30 \\
\hline Total & 183 & 1,343 & 62 & 2,442 & 189 & 596 & 4,792 \\
\hline
\end{tabular}

Source: GIZ 2020.

blished the production of multi-megawatt class wind turbines (Bilozerova 2012). The volume of investments amounted to EUR 3 million, the number of highly qualified jobs created - 150 and 100, respectively (Efimov 2018). In fact, a territorial-industrial cluster for the production of equipment for wind energy with a closed production cycle was formed.

Given that the installation of one wind farm brings to the region up to EUR 4 million, significantly revives the activities of related industries (launch of one turbine creates hundreds of jobs 
in engineering, construction, transport, maintenance of aircraft), and its estimated operation life is 25 years (Efimov 2018), wind energy not only increases the country's energy independence, but also creates long-term preconditions for socio-economic stability: the effect on employment is determined by the amount of income from investment and operation (a small wind farm creates about 50 jobs).

\section{Employment in the field of energy efficiency in Ukraine}

An important reserve for increasing employment in Ukraine is to ensure the energy efficiency of buildings. At the beginning of 2020, Ukraine approved the concept for the implementation of state policy in the field of energy efficiency of buildings in terms of increasing the number of nearly zero-energy buildings and approved the relevant National Action Plan until 2025 (RADA 2020).

The total employment potential in this area is estimated at 465 thousand jobs in all sectors of the economy for workers employed in energy modernization of buildings and 1135 jobs for energy auditors The United States, invested USD 1 billion in energy efficiency projects, created 15 to 20 thousand direct, indirect and induced jobs in the economy (FEAO 2017).

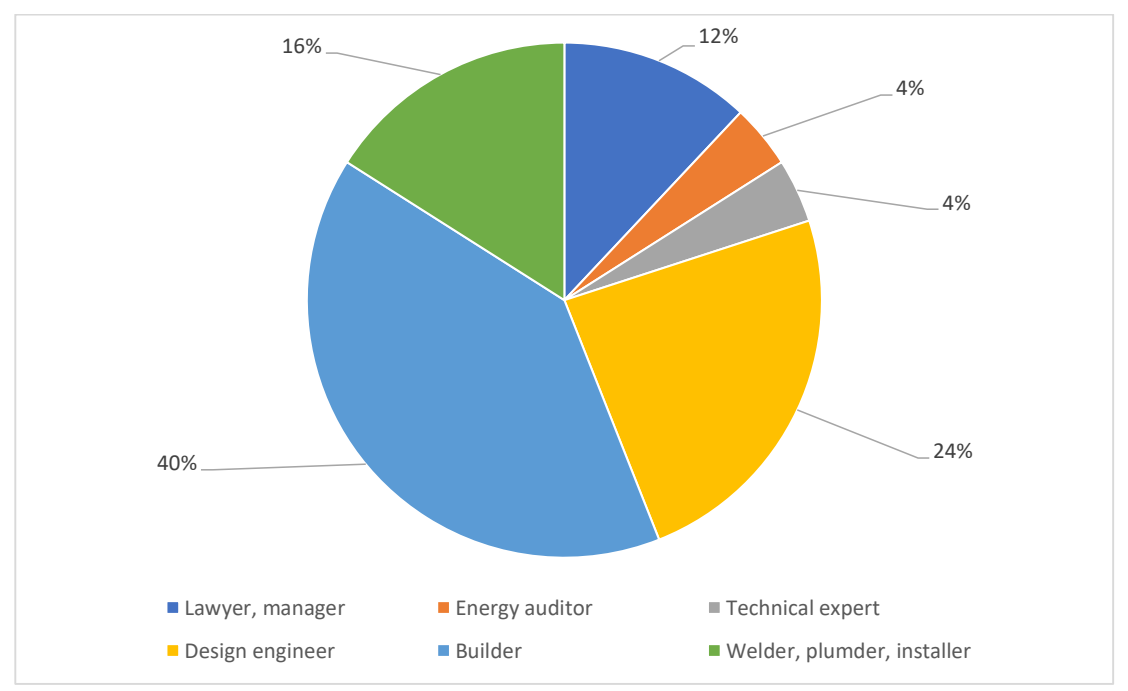

Fig. 5. Structure of potential employment of workers on performance of works on thermal insulation of buildings in Ukraine

Source: GIZ 2020

Rys. 5. Struktura potencjalnego zatrudnienia pracowników przy wykonywaniu prac przy ocieplaniu budynków na Ukrainie 
The total estimated employment potential and performance of works on thermal insulation of residential buildings in Ukraine (carried out on the basis of the methodology of the International Renewable Energy Agency IRENA (IRENA 2017)) is 794,672 jobs: lawyer, manager - 95,361 people; energy auditor - 31,787 people, technical expert - 31,787 people, design engineer 190,721 people, builder -317,869 people, welder, plumber, installer - 127,148 people (GIZ 2020).

The professions of a builder (40\%) and a design engineer $(24 \%)$ have the greatest employment potential when performing thermal insulation works on buildings in Ukraine (Fig. 5).

\section{Staffing of the renewable energy sector in Ukraine}

The development of renewable energy in Ukraine involves the creation of jobs with a high level of skills of employees. At the same time, according to the results of the survey of 37 companies in the sector on staffing (25 companies representing renewable energy, 7 - energy efficiency, 5 operating in both sectors), conducted by the European-Ukrainian Energy Association (GIZ 2020), $89.2 \%$ of companies noted a shortage of qualified personnel, with $67.6 \%$ of respondents considering it as very significant (Fig. 6). Thus, among equipment companies, $75 \%$ experience a very significant shortage of qualified technicians and specialists in the field of innovative technologies.

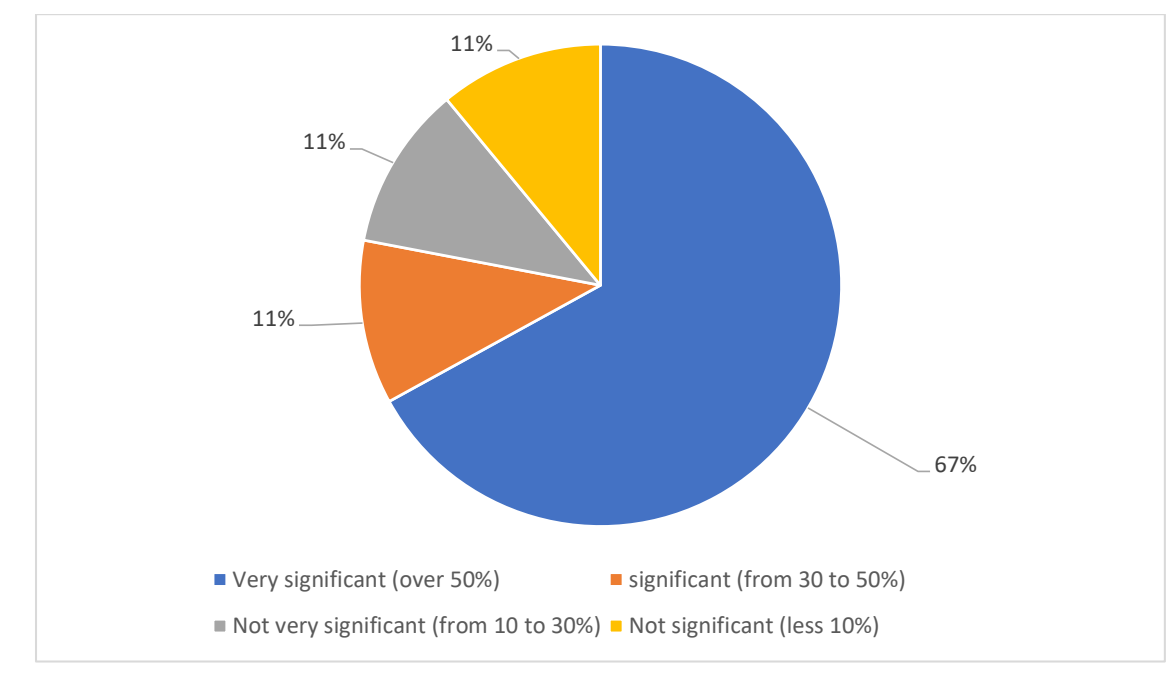

Fig. 6. Distribution of companies operating in the field of renewable energy and energy efficiency in Ukraine, according to the degree of shortage of qualified personnel Source: GIZ 2020

Rys. 6. Rozkład firm działających w zakresie energii odnawialnej i efektywności energetycznej na Ukrainie według stopnia niedoboru wykwalifikowanej kadry 
Importantly, the vast majority of respondents (89.2\%) reported an increase in the number of skilled workers in the field of renewable energy and energy efficiency over the last five years. At the same time, since the same share of respondents invest their own funds in the development and training of existing staff, we can conclude that the issues of labor support in the industry are solved exclusively at the enterprise level.

\section{Conclusions}

The development of the energy sector of Ukraine's economy is in line with the long-term strategy of the state's energy sector, which determines the directions of development of the renewable energy sector and determines the transformation of employment in the industry. Ukraine has a significant untapped potential for energy efficiency, which requires accelerating the pace of modernization and development of renewable energy sources and highlights the problem of providing the industry with labor resources capable of promoting a green energy transition.

The formation in Ukraine of territorial-industrial clusters for the production of equipment for solar and wind energy with a closed production cycle forms long-term prerequisites for socio-economic stability in the country and stimulates employment. At the same time, there is a significant shortage of qualified workers in the field of renewable energy and energy efficiency in Ukraine. Today, the solution of the issue of labor support of the industry is mainly at the level of enterprises that invest in the development of their own staff.

\section{References}

Aldieri et al. 2020 - Aldieri, L., Grafström, J., Sundström, K. and Vinci, C.P. 2020. Wind Power and Job Creation. Sustainability 12(1), DOI: 10.3390/su12010045.

Bilozerova, L. 2012. Wind energy relies on domestic producers (Vitroenerhety'ka rozrakhovuye na vitchy'znyanoho vy'robny'ka). [Online] http://www.golos.com.ua/article/69204/ [Accessed: 2020-05-22] (in Ukrainian).

EAP 2018. Prospects for the development of the green economy in Ukraine: opportunities for greening the energy sector. Analytical review (Perspekty'vy' rozvy'tku "Zelenoyi” ekonomiky'v Ukrayini: mozhly'vosti dlya "ozelenennya” enerhety'chnoho sektoru. Anality'chnyy ohlyad). [Online] http://www. green-economies-eap.org/ru/resources/Ukraine\%20Energy\%20UKR\%2027\%20Jun.pdf. [Accessed: 2020-09-06] (in Ukrainian).

Efimov, M. 2018. Wind energy as a locomotive of economic development of the country (Vitroenerhety'ka yak lokomoty'v ekonomichnoho rozvy'tku krayiny'). [Online] https://investgazeta.ua/ blogs/vitroenergetika-yak-lokomotiv-ekonomichnogo-rozvitku-krajini [Accessed: 2020-05-22] (in Ukrainian). 
FEAO 2017. Presentation in the Verkhovna Rada of a study on job creation in the field of energy efficiency (Prezentatsiya u vru doslidzhennya shchodo stvorennya robochy'kh mists' u sferi enehroefekty'vnosti). [Online] https://feao.org.ua/news/present-job-creation/ [Accessed: 2020-07-16] (in Ukrainian).

GIZ 2020. Research on job creation in the fields of energy efficiency and renewable energy in Ukraine (Doslidzhennya stvorennya robochy' $k$ h mists ' $u$ sferakh enerhoefekty'vnosti ta vidnovlyuvanoyi enerhety 'ky' $v$ Ukrayini). [Online] http://reform.energy/media/1463/b46d83bca4c4d68ed98f1807262d702c.pdf. [Accessed: 2020-09-10] (in Ukrainian).

IEA 2020. Global Energy Review 2020. [Online] https://www.iea.org/reports/global-energy-review-2020 [Accessed: 2020-09-10].

IEA U 2020. Global Energy Review 2020. Ukraine. [Online] https://www.iea.org/countries/ukraine [Accessed: 2020-09-10].

IRENA. International Renewable Energy Agency. [Online] https://www.irena.org/ [Accessed: 2020-09$-10]$.

IRENA 2017. Renewable Energy Benefits: Leveraging Local Capacity for Solar PV. [Online] https://irena. org/publications/2017/Jun/Renewable-Energy-Benefits-Leveraging-Local-Capacity-for-Solar-PV [Accessed: 2020-09-10].

IRENA 2019. Renewable Energy and Jobs. Annual Review 2019. IRENA. [Online] https://www.irena.org/ publications/2019/Jun/Renewable-Energy-and-Jobs-Annual-Review-2019 [Accessed: 2020-09-10].

Kness 2019. KNESS PV became the first national industrial manufacturer of solar panels in Ukraine (KNESS $P V$ stav pershy'm natsional'ny'm promy'slovy'm vy'robny'kom sonyachny'kh paneley $v$ Ukrayini). [Online] https://kness.energy/news/opening-of-the-kness-pv/ [Accessed: 2020-09-06] (in Ukrainian).

Kyiinfo 2020. Does the labor market keep up with changes in the energy sector? (Chy vstyhaye rynok pratsi za zminamy $v$ sektori enerhetyky?). [Online] https://kyiinfo.com.ua/chy-vstygaye-rynok-pratsi-za-zminamy-v-sektori-energetyky/ [Accessed: 2020-09-05] (in Ukrainian).

MEPR 2017. Energy strategy of Ukraine for the period up to 2035 "Security, energy efficiency, competitiveness" (Enerhety'chna stratehiya Ukrayiny' na period do 2035 roku 'Bezpeka, enerhoefekty'vnist', konkurentospromozhnist"”). [Online] https://mepr.gov.ua/news/34422.html [Accessed: 2020-09-02] (in Ukrainian).

MEPR 2020. The concept of "green" energy transition of Ukraine until 2050 (Kontseptsiya "zelenoho" enerhety'chnoho perekhodu Ukrayiny' do 2050 roku). [Online] https://mepr.gov.ua/news/34424.html [Accessed: 2020-09-10] (in Ukrainian).

MPE 2017. Ukraine's energy strategy for the period up to 2035 (Enerhety'chna stratehiya Ukrayiny'na period do $2035 \mathrm{roku}$ ). [Online] http://mpe.kmu.gov.ua/minugol/control/uk/doccatalog/list?currDir=50358 [Accessed: 2020-09-07] (in Ukrainian).

RADA 2020. On approval of the Concept for the implementation of state policy in the field of energy efficiency of buildings in terms of increasing the number of buildings with close to zero energy consumption and approval of the National Plan to increase the number of buildings with close to zero energy consumption (Pro skhvalennya Kontseptsiyi realizatsiyi derzhavnoyi polity'ky u sferi zabezpechennya enerhety'chnoyi efekty'vnosti budivel' u chasty'ni zbil'shennya kil'kosti budivel'z bly'z'ky'm do nul'ovoho rivnem spozhy'vannya enerhiyi ta zatverdzhennya Natsional'noho planu zbil shennya kil'kosti budivel'z bly'z'kym do nul'ovoho rivnem spozhy'vannya enerhiyi). [Online] https://zakon.rada.gov. ua/laws/show/88-2020-\%D1\%80\#Text [Accessed: 2020-09-02] (in Ukrainian).

SAEE 2020. Alternative energy. State Agency on Energy Efficiency and Energy Saving of Ukraine (Al'ternaty'vna enerhety' $k a$. Derzhavne ahentstvo z enerhoefekty'vnosti ta enerhozberezhennya Ukrayiny'). [Online] https://saee.gov.ua/uk/ae [Accessed: 2020-09-07] (in Ukrainian). 


\section{Rozwój energetyki odnawialnej na Ukrainie w kontekście zapewnienia zatrudnienia}

\section{Streszczenie}

Artykuł analizuje trendy rozwoju energetyki odnawialnej na Ukrainie zgodnie z długoterminową strategią sektora energetycznego państwa w kontekście transformacji zatrudnienia w sektorze energetycznym kraju. Podkreśla się, że inwestycje w technologie energii odnawialnej tworzą więcej miejsc pracy w porównaniu z tradycyjnymi technologiami wytwarzania energii elektrycznej. Na Ukrainie istnieje znaczny, niewykorzystany potencjał efektywności energetycznej, co wymaga przyspieszenia tempa modernizacji i rozwoju odnawialnych źródeł energii. To powoduje, że pojawia się kwestia możliwości zapewnienia dostępności pracowników w przemyśle. Podkreśla się, że możliwości rozwoju sektora energetycznego Ukrainy są związane z rozwojem odnawialnych źródeł energii. Powstanie na Ukrainie klastrów terytorialno-przemysłowych do produkcji urządzeń do energetyki słonecznej i wiatrowej o zamkniętym cyklu produkcyjnym stanowi długoterminową przesłankę stabilności społeczno-gospodarczej kraju i stymuluje zatrudnienie.

Wskazano, że ważnym elementem zwiększenia zatrudnienia jest zapewnienie efektywności energetycznej budynków. Jednocześnie zauważono, że w obszarze energetyki odnawialnej i efektywności energetycznej na Ukrainie występuje znaczny niedobór wykwalifikowanych techników i specjalistów z zakresu innowacyjnych technologii, co potwierdza istotność badań związanych z problematyką wsparcia rynku pracy w przemyśle.

Oceniono, że dziś rozwiązanie problemu podaży pracy w przemyśle następuje głównie na poziomie przedsiębiorstw inwestujących w rozwój własnej kadry.

SŁowa KLUCzowe: energia odnawialna, efektywność energetyczna, elektryczność, energia słoneczna, energia wiatrowa, zatrudnienie, podaż pracy 